\title{
Outcome of Unstable Thoracolumbar Fracture Following Long Segment Posterior Fixation
}

\author{
AAM CHOUDHURY ${ }^{a}$, MS ALAM ${ }^{b}$, AK AZAD $^{c}$, K AKTER $^{\mathrm{d}}$
}

\begin{abstract}
:
Introduction: Fractures of the thoracolumbar region are the most common injuries of the vertebral column and burst fractures are the most frequent. The purpose of this study was to see the radiological and functional outcome after long segment posterior fixation in unstable thoracolumbar spine injury with incomplete neurological deficit.
\end{abstract}

Methods: A total of 146 cases were included in this prospective case series from January 2014 to December 2018 through non randomized purposive sampling. All the patients were operated with long segment posterior fixation and postero-lateral fusion by Autogenous cancellous bone graft. Postoperative functional outcome was assessed both clinically by ODI, VAS, ASIA and radiologically by

\section{Introduction:}

Thoracolumbar fracture is the commonest injury of the axial skeleton and accounts for around $90 \%$ ofall spinal fractures. Due of the rigid costotransverse joints of the dorsal spine, it acts as a fulcrum of movement in dorsolumbar spine at the time of injury ${ }^{1}$.

Thoracolumbar fractures are frequent in men and peak incidence is observed between 20 and 40 years.

a. Dr. Abdullah Al Mamun Choudhury, Medical Officer, National Institute of Traumatolog \& Orthopaedic Rehabilitation, (NITOR) Dhaka

b. Prof. Dr. Md. Shah Alam, Professor \& Head of the Depertment, Orthpaedics \& Spine Surgery, Dhaka Medical College Hospital, Dhaka

c. Dr. Abul Kalam Azad Junior Consultant (Ortho), General Hospital Netrokona

d. Dr. Kohinoor Akhter, MD Resident (Biochemistry \& Moleculer Biology), BSMMU

Address of Correspondence: Dr. Abdullah Al Mamun Choudhury, Medical Officer, National Institute of Traumatolog \& Orthopaedic Rehabilitation, (NITOR) Dhaka, E/3, 5th floor, Kalim Vila, 104/A/16/11, Sahid Buddhijibi Road, Jafrabad, Mohammadpur, Dhaka, Cell: +8801714575282, E-mail: mamuncomc@gmail.com Received: 25 March, 2019 Accepted: 06 March, 2021
Bridwell criteria. Postoperative follow up was conducted at $2^{\text {nd }}, 6^{\text {th }}, 12^{\text {th }}$ and finally 6 monthly.

Results: The mean Cobb angle at pre-operative was $21.5 \pm 8.9$ and at final follow-up was $11 \pm 4.57$ in this study (p-value<0.05). At final follow up 1 grade improvement occurred in 116(79.5\%) patients and 2 grade improvement in 36 (20.5\%). Regarding ODI and VAS, moderate disability (25\%) with mild pain (16\%) was found at final follow up with a Bridwell fusion grade II (48\%).

Conclusion: Long segment transpedicular screw fixation in unstable thoracolumbar spine injury with incomplete neurological deficit is an effective method of treatment. This method enhances neurological and functional recovery with an acceptable fusion rate

(J Bangladesh Coll Phys Surg 2021; 39: 114-122)

DOI: https://doi.org/10.3329/jbcps.v39i2.52410

$65 \%$ of thoracolumbar fractures occur due to motor vehicle injuries and fall from height, with reminder contributed by sports injury and violence ${ }^{2}$.

Due to the fulcrum of increased motion at dorsolumbar junction, collapse of the vertebral body with associated kyphotic deformity usually occurs. This vertebral collapse usually invades the spinal canal, which may cause neurological Deficit ${ }^{3}$.

Unstable fracture defined as failure of any two column injury including middle column which account for $25 \%-50 \%$ of all fractures in this region. They are very common in younger patients and could have a great impact on their daily physical activities $^{4}$.

There are standard classification systems based on fracture pattern, mechanism of injury, neuro-deficit and posterior ligamentous complex (PLC) injury. Xrays are the main investigation while computed tomography (CT) scan delineates the extent on bony injury and magnetic resonance imaging (MRI) scan detects the spinal cord and soft tissue injury ${ }^{5}$. 
The assessment of neurological function is done by using the American Spinal Injury Association (ASIA) method and graded according to the ASIA Impairment scale. Examination of anal sensation and sphincter autonomic contraction should be performed to identify complete or incomplete neurological deficit as a standard protocol ${ }^{6}$.

The management of unstable thoracolumbar fractures remains challenging. Effective correction of the deformity, neurological recovery, early mobilization and return to work are the fundamentals of the management, and also minimize complication.

Absolute indication of early surgery is progressive neurological deficit ${ }^{7}$. Other indication for surgical intervention are incomplete neurological deficit, $>25-300$ angle of kyphotic deformity, $>50 \%$ of loss of vertebral body height, and $>40-50 \%$ of canal narrowing ${ }^{8}$.

The surgical treatment of unstable fracture and fracture-dislocations of thoracolumber spine are still in debate. Conservative treatment might be an option, but surgery is the modern way of treatment. The goals of surgery are to restore the stability of the vertebral column and decompression of spinal canal (9). Posterior transpedicular fixation has been the choice for stabilizing acute unstable thoracolumbar fractures among all other methods ${ }^{10}$.

Either anterior or posterior or both approaches can be used to stabilize and achieve fusion but the efficacy of either approach is somewhat similar ${ }^{11,12}$. Due to less extensile and hazardous approach, most of the spine surgeons advocate posterior fusion as the treatment of choice ${ }^{13-15}$.

Long-segment pedicle screw fixation (LSPF) usually involves inserting eight screws: two level above \& below the fracture. Short- segment pedicle fixation (SSPF) involves inserting four screws: one level above $\&$ below the fracture ${ }^{16}$.

SSPF is the most common and simple treatment. It offers the advantage of incorporating fewer motion segments in the fusion ${ }^{17,18}$. but may lead to implant failure and re-kyphosis (9-54\%) and moderate-to-severe $(50 \%)$ pain $^{9,17}$. To prevent this and augment the anterior column, placement of body augmente, ${ }^{19}$ polymethylmethacrylate injection ${ }^{3}$, transpedicular bone grafting ${ }^{20}$, anterior instrumentation and strut grafting ${ }^{12}$ or long-segment posterior fixation (LSPF) ${ }^{21}$ could be done.
The use of transpedicular fixation two levels above and below the fractured vertebra reduce the kyphosis, instrument failure and collapse of the vertebrae $^{22}$. LSPF has gained popularity in the last decade as it has the aforementioned advantages as well as relieve pain sufficiently ${ }^{23}$.

\section{Methods:}

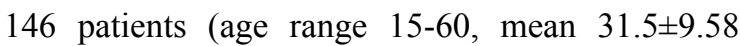
years) with thoracolumbar fracture (T10- L2) with incomplete neurological deficit from January2014 to December 2018, studied in NITOR and private settings were included in this study. Inclusions criteria were: a) single-level fracture; b) neurologic function limited to ASIA Grades B, C, or D; c) limited involvement of T10-L2; d) $<3$ weeks from the time of injury, Exclusion criteria were: a) Complete spinal cord injury (ASIA Grades A) b) Associated cervical spine \& head injury; c) Pathological fracture of spine. This was a prospective case series and cases were selected by purposive sampling.

Radiographic outcome was evaluated by measuring Cobb angle, kyphotic deformation and beck index (24). Figure 2 shows measurement of Cobb Angle and kyphotic deformation. Pain status was evaluated by a 100-point VAS scale. The functional outcome was assessed by Owestry Disability Index (ODI). Neurological recovery was evaluated by ASIA grading. The investigation included X-ray, computed tomography (CT) scanning of the spine and magnetic resonance imaging (MRI).

Informed written consent was taken from all the patients mentioning the details of the procedure as well as modalities of treatment. An expert technologist was responsible for gathering the required information who is unaware of the objectives and surgical procedures of this study.

Long segment posterior fixation (LSPF) was done in every cases and performed by the same surgeon. Patients were placed in a prone position under general anesthesia with modified kneeling with two sand bags under each side of trunk which allowed the abdomen to hang free, minimizing epidural venous dilation and bleeding. Pedicle screw fixation and reduction were performed under $\mathrm{C}$-arm guidance. Laminectomy to decompress spinal cord was carried out at the involved level and bone was saved to be used as bone graft. Screws were 40 or $45 \mathrm{~mm}$ long, depending on the level and size of the vertebra. At the10th and 11th thoracic levels, 5.5 or 6.5mmdiameter multiaxial screws and at the12th 
thoracic level and caudally $6.5 \mathrm{~mm}$ diameter multiaxial screws were used. The instrumentation was applied bilaterally. Fracture reduction and indirect spinal canal decompression both could be accomplished by contouring the rod and applying compression-distraction forces before tightening the screws. Long segment posterior fixation was done with autogenous bone grafting from the spinous process and lamina in all patients and applied thoracolumbosacral orthosis (Taylor brace) postoperatively for 3 months. Figure 1 shows Burst \# L2 in a 28 years' male, fixed with LSPF.

A fracture severity score was constructed using Thoracolumbar Injury Classification and Severity Score (TLICS). A comprehensive severity score of 3 or less suggests a non-operative injury, while a score of 5 or more suggests that surgical intervention may be considered. Injuries assigned a total score of 4 might be handled conservatively or surgically ${ }^{25}$.

Correction loss was defined as progressive loss of Cobb angle in the latest follow-up radiographs compared to the initial post-operative radiographs. The fusion status of the patients was determined primarily with use of plain radiographs according to the classification system of Christensen et al. $2001^{26}$ by two independent observers and finally by Bridwell fusion grading ${ }^{27}$. The presence of screw breakage, screw pullout, peri-implant loosening, and rod breakage were considered as criteria for implant failure.

Data were collected concerning the age, sex, localization, type of injury, presence of neurological deficits, pain, work status, complications and radiologic parameters (Cobb angle, kyphotic deformation of vertebral body, vertebral height and posterolateral fusion). Clinical and radiographic follow-up were done immediately after the operation and at 2nd, 6th, 12th, 24th week \& then 12 monthly. Statistical analysis was done using SPSS version 25.0 software. The level of statistical significance was set at $\mathrm{P}<0.05$.

\section{Results:}

There were 126 men and 20 women with male to female ratio were $6.3: 1$. Mean age was 31.5 years within the range of 31-45 years. Maximum 64 patients were manual worker. The majority of fractures were due to falls (106 cases). The remaining cases were due to car accidents ( 40 cases). The fractured vertebra body level was L1, L2, and
T12 in 82, 24, and 40 cases respectively. In this series maximum number of patients (92) operated within 15 to 21 days $(63 \%)$ and maximum fractures were unstable burst in nature $102(70 \%)$.

All the patients were decompressed posteriorly and long segment stabilization was done in each case by titanium pedicle screws and rods. Post-operative Xray showed good hardware position in all patients. Adequate decompression was achieved in all the cases.

The mean duration of surgery was $150 \pm 21 \mathrm{~min}$ whereas the mean blood loss was $392.47 \mathrm{ml}$. The mean length of hospital stay was 28 days and all the patients were mobilized in the 1 st or 2 nd postoperative day. Radiological parameters are listed in Table-1.

A paired sample T-test was conducted to compare the means of radiological parameters which was found statically significant ( $\mathrm{p}$-value $<0.05$ )

The mean Pre and post op VAS is $57.57 \pm 9.08$ and $16.4 \pm 8.9$ (mild) respectively, 90\% (131) of which end up with mild pain ( $\mathrm{p}$-value $<0.05$ ). The mean ODI at final follow up was $25.27 \pm 8.49$ which was $67.68 \pm 13.20$ pre operatively with a p-value $<0.05$. Maximum patients (87) 59.6\% end up with mild disability at final follow-up.

In our series, pre-operative ASIA grade B was 30 (20.5\%), C was 48 (36.9\%) and D was 68 (46.6\%). After final follow up1 grade improvement occurred in $116(79.5 \%)$ patients and 2 grade improvement in $36(20.5 \%)$ patients. A cross-tab analysis was conducted to see the significance of status in Pre-operative and Post-operative ASIA grading with grade impro vemen $\mathrm{t}$. A Pe ar so $\mathrm{n}$ ch i-square $\mathrm{v}$ alu e $<0.05$ indicates significant improvement in terms of neurology post-operatively.

$48 \%$ of cases (70) showed thick fusion mass on one side i.e. bridwell grade II, 60 patients (41\%) showed grade I fusion and rest of patients' had doubtful fusion with lucency.

A non-parametric Spearman correlation test was conducted among Bridwell fusion grade, Final ODI and ASIA grading. There is a significant positive strong correlation between Bridwell fusion gradeand Final ODI exist ( $\mathrm{r}=0.694$, $\mathrm{p}$-value $<0.05, \mathrm{n}=146$ ). But final ASIA grading was not correlated with Bridwell fusion grade ( $p$-value=0.394). Also magnitude of curve correction is not related with Bridwell fusion grade, Final ODI and ASIA grading 


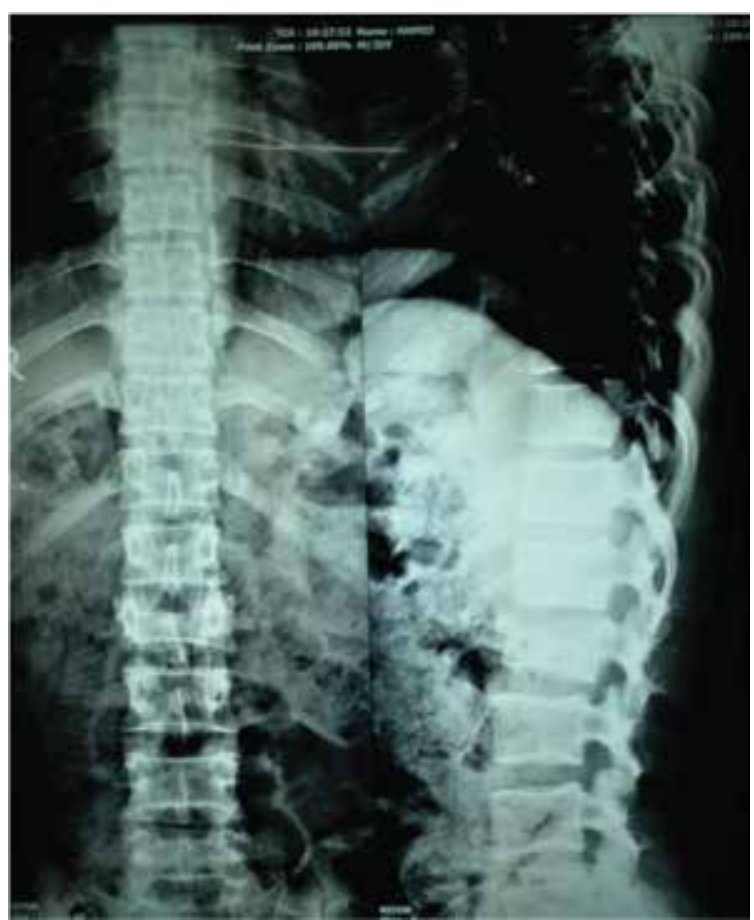

A

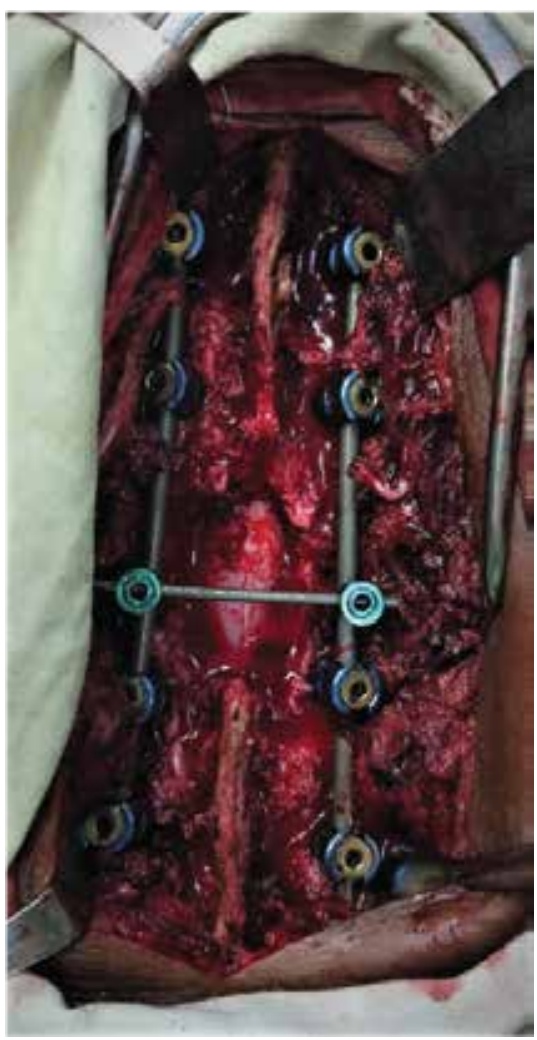

A

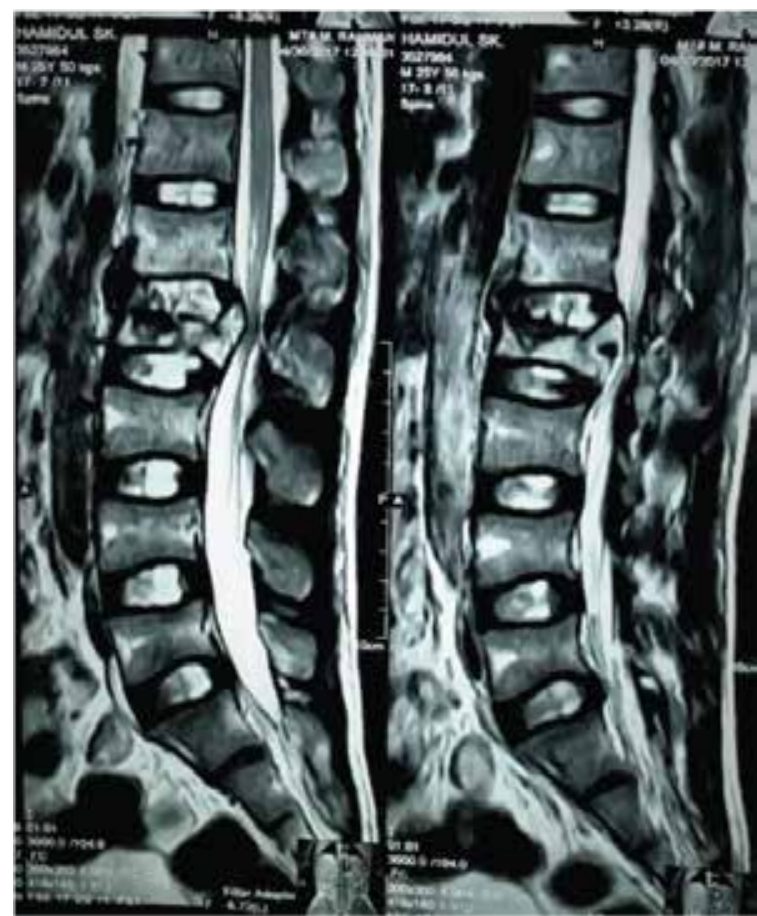

B

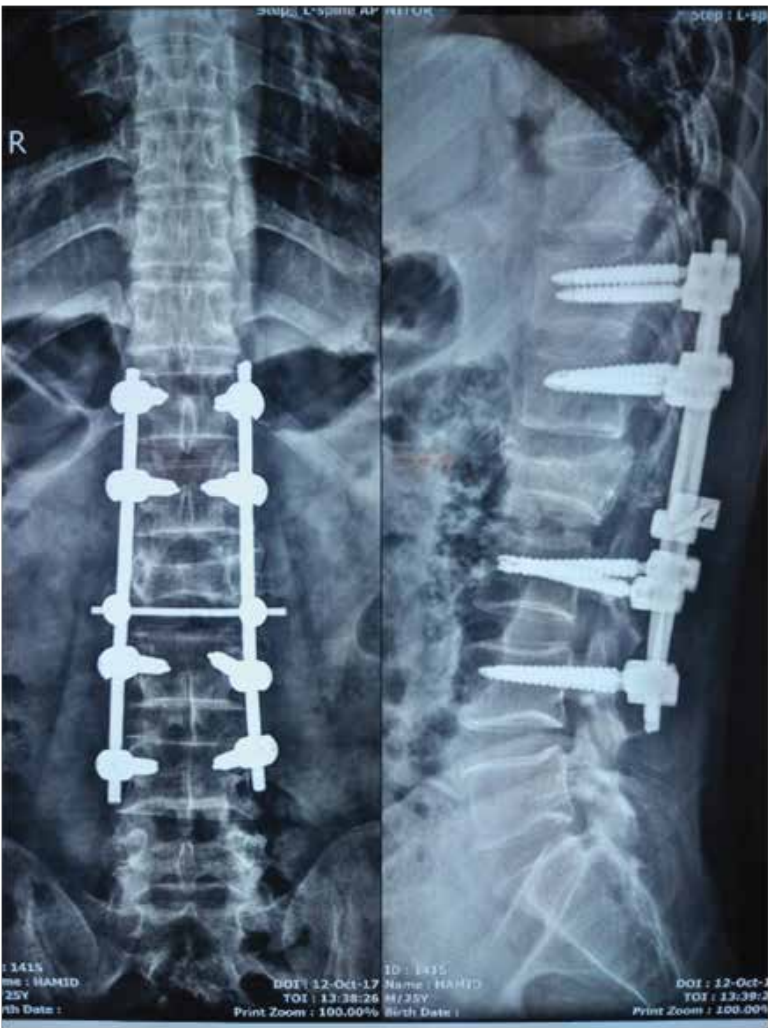

B 
Figure-1:

A. Pre-operative X-ray of LS spine AP \& lateral view, T2 weighted sagittal section (MRI of LS spine) showing Burst \# L2 in a 28 years' Male

B. Per-operative image showing Long segment pedicle fixation with crosslink (same patient)

C. X-ray of LS spine AP \& lateral view at final follow-up (same patient)
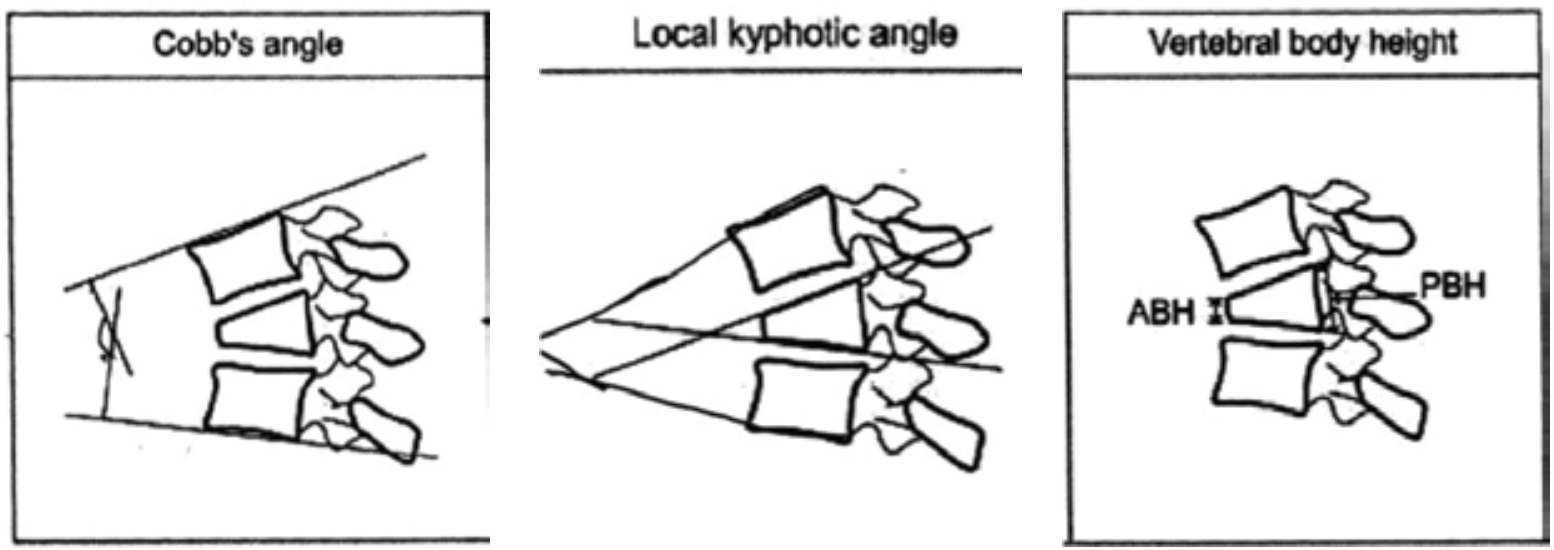

Figure-2: Measurement of cobb's angle, kyphotic deformation/ local kyphotic angle, and Beck Index.

1. Kyphotic angle (Cobb angle) is the angle formed between a line drawn parallel to the superior endplate of upper vertebrae above fracture and inferior endplate of lower vertebra below the fracture.

2. Segmental kyphosis (kyphotic deformation) was measured as the angle between the inferior and superior endplate of fractured vertebra.

3. The ratio of anterior and posterior vertebral body height termed as Beck index.

ABH: anterior body height, PBH: posterior body height.

with a p-value of $0.150,0.819$ and 0.204 respectively.

During the follow-up hardware failure was detected in 3 cases. There were 9 cases of superficial wound infection and bed sore each which were responded to conservative treatment.

\section{References:}

Among all spinal injury thoracolumbar junction is the commonest and comprises $>50 \%$ of the cases of all spinal fractures (28).

Holdsworth, F. (1963) first described the burst fracture (29). The existence of the unstable burst fracture, with complete disruption of the posterior elements and increased potential for neural injury was described in whitesides, 1977(30). It is estimated that approximately $75 \%$ of patients with thoracolumbar injuries sustain some degree of neurological deficit. These types of injuries are best treated by vertebral column decompression and stabilization (31). The management plans differ among many of the researchers regarding operative (32) and non-operative approaches $(33,34)$.

According to literature review the result of our study is almost similar to internationally published studies. It is observed that active age group was mostly affected with a male $126(86.3 \%)$ dominancy. RA raja, (31) showed $86 \%$ male patients in his series. In this study, most common level injured was L1 (56.2\%) and followed by D12 (27.4\%). Altay (16) showed $51.6 \%$ involvement of L1 and $29 \%$ involvement of D12. Muralidhar (35) observed that $70 \%$ were at L1 level and 3 cases at D12 (10\%). 
Maximum injuries were due to fall from height 106 $(72.6 \%)$ in this study which was $92 \%$ and $59.25 \%$ cases observed in some studies $(31,36)$. But other study showed road traffic accident is the common cause of injury (37). Maximum fractures were burst in nature $102(70 \%)$ which were reported $44 \%$ and $83.3 \%(31,35)$ in other studies.

In our series, at final follow up1 grade improvement occurred in $116(79.5 \%)$ patients and 2 grade improvement in 36 (20.5\%). Butt et al., 2006 showed two grades of improvement in $40 \%(7 / 17)$ of the patients and one grade of improvement in 60\%(38).

The mean Cobb angle at pre-operative was $21.5 \pm 8.9$ and at final follow-up was $11 \pm 4.57$ in this study. There was no correlation found between the final amount of Cobb angle and the degree of pain reported. Altay reported Cobb angle at preoperative and final follow up was 18.9 and 8.1 (39) which were near about my result. Similar results $11.9 \pm 2.67$ and 11.4 at final follow up showed by some studies $(40,41)$. But Sapkas, 2010 (15) showed preoperative Cobb angle was $17.5 \pm 6.8$ which became $6.0 \pm 4.0$ degree at final follow up.

Gertzbein (2) noted that, more severe the canal compromise and kyphotic deformity, worse the neurological deficit. But Mumford and Cantor $(33,34)$ stated that the relationship between these two is unclear. In this study the mean preoperative kyphotic deformation of vertebral body was around 21.80 and 14.50 at final follow-up. kyphotic deformation was observed 200 pre-operatively and 30 at final follow-up (42). Mean beck index was found 0.68 pre operatively and 0.80 at final follow up in this study. Sapkas (15) showed similar results where preoperative Beck index was 0.60 and 0.92 at final follow up.

According to functional outcome ODI was $67.68 \%$ (Crippled) pre operatively which became 25.6\% (moderately disabled) at final follow up Aly (43) showed in a meta-analysis that Kim 2009, Canbeck 2014 and Azmiri (44) found similar result which were $30 \%, 29 \%$ and $25 \%$ at last follow up respectively (moderately disabled). In this series, Mean Pre op VAS (pain intensity) was $57 \mathrm{~mm}$ (moderate) and at final follow up it was $17 \mathrm{~mm}$ (mild) Pain intensity according to VAS was pre op $40 \mathrm{~mm}$ post op $4 \mathrm{~mm}$ observed by Yang (45).

Fusion rate with pedicular fixation (99\%) were significantly higher than those for anterior instrumentation (46) In this series, $48 \%$ of cases showed thick fusion mass on one side i.e. bridwell grade II and $41 \%$ shows solid fusion in both sides (grade I).

Regarding the postoperative complication, bed sore and wound infection was found in $9(6.67 \%)$ patients each who were responded to antibiotic later. But Modi (47) reported 1 (3.22\%) screw breakage, 2 $(6.45 \%)$ screw loosening and $1(3.22 \%)$ superficial wound infection.

It was observed that, fusion rate was highest in minimally disabled group. There is a significant positive strong correlation between Bridwell fusion grade and Final ODI exist $(r=0.694$, $p$-value $<0.05$, $\mathrm{n}=146$ ). But final ASIA grading was not correlated with Bridwell fusion grade ( $p$-value $=0.394)$. Also magnitude of curve correction is not related with Bridwell fusion grade, Final ODI and ASIA grading with a p-value of $0.150,0.819$ and 0.204 respectively.

\section{Conclusion}

In countries like Bangladesh fractures of the thoracolumbar spine are increasing in frequency. As seen from the result of this study, Long segment transpedicular screw fixation in unstable thoracolumbar spine injury with incomplete neurological deficit is an effective method of treatment. This method markedly reduce the hospital stay and enhances neurological and functional recovery with an acceptable fusion rate.

\section{Funding: No funding sources}

\section{Conflict of interest: None declared}

\section{References:}

1. Avanzi O, Landim E, Meves R, Caffaro MF, de Albuquerque Araujo Luyten F, Faria AA. Thoracolumbar Burst Fracture: Load Sharing Classification and Posterior Instrumentation Failure. Rev Bras Ortop (English Ed [Internet]. 2010;45(3):236-40. Available from: http://dx.doi.org/ $10.1016 / \mathrm{S} 2255-4971$ (1 5 ) $30363-3$ https://doi.org/10.1016/S2255-4971(15)30363-3

2. Gertzbein S.D., Court-brown, CM., Marks, P., Fazl, M., Schwartz, M., Jacobs RR. The Neurological Outcome following Surgery for Spinal Fractures. Spine (Phila $\mathrm{Pa}$ 1976) [Internet]. 1988;6(13):641-4. Available from:https://journals.lww.com/spinejournal/Abstract/ 1988/06000/The_Neurological_Outcome_following _ Surgery_for.7.aspx https://doi.org/10.1097/ 00007632198806000-00007, PMid:3175754 
3. Ge CM, Wang YR, Jiang SD, Jiang LS. Thoracolumbar burst fractures with a neurological deficit treated with posterior decompression and interlaminar fusion. Eur Spine J. 2011;20(12):2195201. https://doi.org/ 10.1007/ s00586-011-1875-6, PMid:21688000 PMCid:PMC3229728

4. Tian NF, Wu Y Sen, Zhang XL, Wu XL, Chi YL, Mao FM. Fusion versus Nonfusion for Surgically Treated Thoracolumbar Burst Fractures: A Meta-Analysis. PLoS One. 2013;8(5):1-6. https://doi.org/ 10.1371/ journal.pone.0063995, PMid:23704968 PMCid:PMC3660321

5. Rajasekaran S, Kanna RM, Shetty AP. Management of thoracolumbar spine trauma An overview. Indian J Orthop. 2015;49(1):72-82. https://doi.org/10.4103/ $0019-5413.143914, \mathrm{P} \mathrm{Mid:25593358}$ PMCid:PMC4292328

6. Zhang ZC, Li F, Sun TS. An expert consensus on the evaluation and treatment of acute thoracolumbar spine and spinal cord injury in China. Neural Regen Res. 2013;8(33):3077-86.

7. Bohlman HH. Treatment of fractures and dislocations of the thoracic and lumbar spine. J Bone Jt Surg Am [Internet]. 1985;67(1):165-9. Available from: http://www.ncbi.nlm.nih.gov/entrez/query.fcgi?cmd Retrieve \&db=PubMed\&dopt $=$ Citation \&list_uids $=3$ 81446, https://doi.org/10.2106/00004623-198567010-00024

8. Hur J-W. A Comparative Analysis of the Efficacy of Short-Segment Pedicle Screw Fixation with that of Long-Segment Pedicle Screw Fixation for Unstable Thoracolumbar Spinal Burst Fractures. Clin Med Res. 2015;4(1):1. https://doi.org/10.11648/j.cmr.20150401.11

9. Alvine GF, Swain JM, Asher MA, Burton DC. Treatment of thoracolumbar burst fractures with variable screw placement or Isola instrumentation and arthrodesis: Case series and literature review. J Spinal Disord Tech. 2004;17(4):251-64. https://doi.org/ $10.1097 / 01 . b s d .0000095827 .98982 .88$ PMid:15280752

10. Liu L, Gan Y, Zhou Q, Wang H, Dai F, Luo F, et al. Improved monosegment pedicle instrumentation for treatment of thoracolumbar incomplete burst fractures. Biomed Res Int. 2015;2015. https://doi.org/ $10.1155 / 2015 / 357206$, PMid:26097844 PMCid:PMC4434173

11. Danisa OA, Shaffrey CI, Jane JA, Whitehill R, Wang GJ, Szabo TA, et al. Surgical approaches for the correction of unstable thoracolumbar burst fractures: A retrospective analysis of treatment outcomes. J
Neurosurg. 1995;83(6):977-83. https://doi.org/ 10.3171/jns.1995.83.6.0977, PMid:7490641

12. Kaneda K, Taneichi H, Abumi K, Hashimoto T, Satoh S, Fujiya M. Anterior decompression and stabilization with the Kaneda device for thoracolumbar burst fractures associated with neurological deficits. J Bone Jt Surg - Ser A. 1997;79(1):69-83. https://doi.org/ $10.2106 / 00004623-199701000-00008$ PMid:9010188

13. Roy-Camille R, Saillant G, Mazel C. Internal fixation of the lumbar spine with pedicle screw plating. Clin Orthop Relat Res. 1986;NO. 203(September):7-17. https://doi.org/10.1097/00003086-198602000-00003

14. Carl, Allen L., MD*; Tromanhauser, Scott G., MD†; Roger, Douglas J. M. Pedicle Screw Instrumentation for Thoracolumbar Burst Fractures and FractureDislocations. Spine (Phila Pa 1976) [Internet]. 17(suppliment 8s):317-24. Available from: https://journals.lww.com/spinejournal/Abstract/1992/ 08001/Pedicle_Screw_Instrumentation_for_Thoracol umbar.18.aspx, https://doi.org/ 10.1097/ 00007632199208001-00018, PMid:1523519

15. Sapkas G, Kateros K, Papadakis SA, Brilakis E, Macheras G, Katonis P. Treatment of Unstable Thoracolumbar Burst Fractures by Indirect Reduction and Posterior Stabilization: Short-Segment Versus Long-Segment Stabilization. Open Orthop J. 2010;4(1):7-13. https://doi.org/10.2174/ 187432500 1004010007, PMid:20177428 PMCid:PMC2822149

16. Altay M, Ozkurt B, Aktekin CN, Ozturk AM, Dogan Ö, Tabak AY. Treatment of unstable thoracolumbar junction burst fractures with short- or long-segment posterior fixation in magerl type a fractures. Eur Spine J. 2007;16(8):1145-55. https://doi.org/10.1007/ s00586007-0310-5,PMid:17252216 PMCid:PMC2200786

17. Alanay A, Acaroglu E, Yazici M, Oznur A, Surat A. Short-Segment Pedicle Instrumentation of Thoracolumbar Burst Fractures. Spine (Phila Pa 1976). 2001;26(2):213-7. https://doi.org/10.1097/ 00007632-200101150-00017, PMid:11154543

18. Knop C, Bastian L, Lange U, Oeser M, Zdichavsky M, Blauth M. Complications in surgical treatment of thoracolumbar injuries. Eur Spine J. 2002;11(3):214-26. https://doi.org/10.1007/s00586-001-0382-6, PMid:12107790 PMCid:PMC3610522

19. Chen HH, Wang WK, Li KC, Chen TH. Biomechanical effects of the body augmenter for reconstruction of the vertebral body. Spine (Phila Pa 
1976). 2004;29(18):382-7. https://doi.org/10.1097/ 01.brs.0000139308.65813.70, PMid:15371717

20. Daniaux H1, Seykora P, Genelin A, Lang T KA. Application of posterior plating and modifications in thoracolumbar spine injuries. Indication, techniques, and results. Spine (Phila Pa 1976). 1991;16(supp. 3):s:125-133. https://doi.org/10.1097/00007632-1991 03001-00018, PMid:2028327

21. Akbarnia, B A; Crandall, D G; Burkus, K; Matthews $\mathrm{T}$. Use of long rods and a short arthrodesis for burst fractures of the thoracolumbar spine. A long-term follow-up study. JBJS [Internet]. 1994;76(11): 1629-35. Available from: https://journals.lww.com/ jbjsjournal/Abstract/1994/11000/Use_of_long_rods_ and a short arthrodesis for burst.5.aspx https://doi.org/10.2106/00004623-199411000-00005 PMid:7962022

22. Aligizakis A, Katonis P, Stergiopoulos K, Galanakis I, Karabekios S, Hadjipavlou A. Functional outcome of burst fractures of the thoracolumbar spine managed non-operatively, with early ambulation, evaluated using the load sharing classification. Acta Orthop Belg. 2002;68(3):279-87.

23. McLain RF. The biomechanics of long versus short fixation for thoracolumbar spine fractures. Spine (Phila Pa 1976). 2006;31(11 SUPPL.):70-9. https://doi.org/10.1097/01.brs.0000218221.47230.dd PMid: 16685240

24. Kang S-K, Lee CW, Park NK, Kang T-W, Lim J-W, Cha KY, et al. Predictive Risk Factors for Refracture after Percutaneous Vertebroplasty. Ann Rehabil Med. 2011;35(6):844. https://doi.org/10.5535/arm.2011.35. 6.844, PMid:22506213 PMCid:PMC3309392

25. Vaccaro AR, Lehman RA, Hurlbert RJ, Anderson PA, Harris M, Hedlund R, et al. A New Classification of Thoracolumbar Injuries. Spine (Phila Pa 1976). $20005 ; 30\left(\begin{array}{lllllllll}2 & 0\end{array}\right): 2325-3$. https://doi.org/10.1097/01.brs.0000182986.43345.cb PMid:16227897

26. Christensen FB, Laursen M, Gelineck J, Eiskjær SP, Thomsen K, Bünger CE. Interobserver and Intraobserver Agreement of Radiograph Interpretation With and Without Pedicle Screw Implants. Spine (Phila Pa 1976). 2001;26(5):538-43. https://doi.org/ $10.1097 / 00007632-200103010-00018$, PMid:11242382

27. Bridwell, Keith H., MD*; Lenke, Lawrence G., MD*; McEnery, Kevin W., MD†; Baldus, Christy, LPN*; Blanke, Kathy R. Anterior Fresh Frozen Structural
Allografts in the Thoracic and Lumbar Spine: Do They Work If Combined With Posterior Fusion and Instrumentation in Adult Patients With Kyphosis or Anterior Column Defects? Available from: https://journals.lww.com/spinejournal/Abstract/1995/ 06020/Anterior_Fresh_Frozen_Structural_Allografts in the.14.aspx, https://doi.org/10.1097/00007632199506020-00014, PMid:7676341

28. Dai LY, Jiang LS, Jiang SD. Posterior short-segment fixation with or without fusion for thoracolumbar burst fractures: A five to seven-year prospective randomized study. J Bone Jt Surg - Ser A. 2009;91(5):1033-41. https://doi.org/10.2106/JBJS.H. 00510, PMid:19411450

29. Denis F. Spinal instability as defined by the three-column spine concept in acute spinal trauma. Clin Orthop Relat Res. 1984;NO. 189:65-76. https://doi.org/10.1097/00003086-198410000-00008

30. Jr TW. Traumatic kyphosis of the thoracolumbar spine. [Internet]. Clinical orthopaedics and related research. 1977. Available from: http://ukpmc.ac.uk/ abstract/MED/340100

31. Raja RA. Management of thoracolumbar spine injuries at a tertiary care hospital. J Ayub Med Coll Abbottabad. 2010;22(1):171-5.

32. McCullen G, Vaccaro AR, Garfin SR. Thoracic and lumbar trauma: Rationale for selecting the appropriate fusion technique. Orthop Clin North Am. 1998;29(4):813-28. https://doi.org/10.1016/S0030-58 98(05)70050-X

33. Cantor, Jeffrey B., MD; Lebwohl, Nathan H., MD; Garvey, Timothy, MD; Eismont, Frank J. M. Nonoperative Management of Stable Thoracolumbar Burst Fractures With Early Ambulation and Bracing. Spine (Phila Pa 1976) [Internet]. 1993;18(8):971-6. Available from: https://journals.lww.com/ spinejournal/ Abstract/1993/06150/Nonoperative_Management_of S t a ble_ Thoracol u m bar. 4. a s p x https://doi.org/10.1097/00007632-199306150-00004 PMid:8367784

34. Mumford, Joe, MD; Weinstein, James N., DO; Spratt, Kevin F., PhD; Goel, Vijay K. P. Thoracolumbar Burst Fractures: The Clinical Efficacy and Outcome of Nonoperative Management. Spine (Phila Pa 1976).

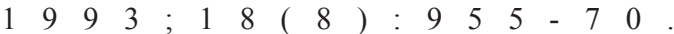
https://doi.org/10.1097/00007632-199306150-00003

35. Muralidhar BM, Hegde D, Hussain PSB. Management of unstable thoracolumbar spinal fractures by pedicle screws and rods fixation. J Clin Diagnostic Res. 2014; 
36. Lee GW, Jang SJ, Kim J Do, Son JH, Jang JH. The efficacy of percutaneous long-segmental posterior fixation of unstable thoracolumbar fracture with partial neurologic deficit. Asian Spine J. 2013;7(2):81-90. https://doi.org/10.4184/asj.2013.7.2.81 PMid:23741544 PMCid:PMC3669707

37. Payer M. Implantation of a distractible titanium cage after cervical corpectomy: Technical experience in 20 consecutive cases. Acta Neurochir (Wien). $20006 ; 1448\left(\begin{array}{cc}1 & 1\end{array}\right): \begin{array}{lllllll}1 & 7 & 3 & - & 8 & 0\end{array}$. https://doi.org/10.1007/s00701-006-0871-9 PMid:16927030

38. Butt MF, Farooq M, Mir B, Dhar AS, Hussain A, Mumtaz M. Management of unstable thoracolumbar spinal injuries by posterior short segment spinal fixation. Int Orthop. 2007;31(2):259-64. https://doi.org/10.1007/s00264-006-0161-4 PMid:16783550 PMCid:PMC2267576

39. Altay M, Ozkurt B, Aktekin CN, Ozturk AM, Dogan Ö, Tabak AY. Treatment of unstable thoracolumbar junction burst fractures with short- or long-segment posterior fixation in magerl type a fractures. Eur Spine J. 2007 Aug;16(8):1145-55. https://doi.org/10.1007/ s00586-007-0310-5, PMid:17252216 PMCid:PMC2200786

40. Moon MS, Choi WT, Moon YW, Kim YS, Moon JL. Stabilisation of fractured thoracic and lumbar spine with Cotrel-Dubousset instrument. J Orthop Surg. 2003;11(1):59-66. https://doi.org/10.1177/230949900 301100113, PMid:12810974

41. Cho DY, Lee WY, Sheu PC, Sonntag VKH, Hitchon PW, Cooper PR, et al. Treatment of Thoracolumbar Burst Fractures with Polymethyl Methacrylate Vertebroplasty and Short-segment Pedicle Screw
Fixation. Neurosurgery. 2003; https://doi.org/ 10.1227/01.NEU.0000093200.74828.2F, PMid:14633301

42. Jun DS, $\mathrm{Yu} \mathrm{CH}, \mathrm{Ahn}$ BG. Posterior direct decompression and fusion of the lower thoracic and lumbar fractures with neurological deficit. Asian Spine J. 2011;5(3):146-54. https://doi.org/10.4184/ asj.2011.5.3.146, PMid:21892386 PMCid:PMC3159062

43. Aly TA. Short segment versus long segment pedicle screws fixation in management of thoracolumbar burst fractures: Meta-analysis. Asian Spine J. 2017;11(1):150-60. https://doi.org/10.4184/asj.2017. 11.1.150, PMid:28243383 PMCid:PMC5326724

44. Azimi P, Shahzadi S, Mohammadi HR, Azhari S. Surgical outcomes and correlation ODI and ASIA scores in patients with thoracolumbar and lumbar burst fractures. Int Clin Neurosci J. 2015;2(1):12-5.

45. Yang WE, Ng ZX, Miang K, Koh R. Percutaneous pedicle screw fixation for thoracolumbar burst fracture: a Singapore experience. singapur Med J. 2012;53(9):3-7.

46. Boos N, Webb JK. Pedicle screw fixation in spinal disorders: A European view. Eur Spine J. 1997;6(1):2-18. https://doi.org/10.1007/BF01676569 https://doi .org/10.1007/ B F 00307823 PMCid:PMC3454634

47. Modi HN, Chung KJ, Seo IW, Yoon HS, Hwang JH, Kim HK, et al. Two levels above and one level below pedicle screw fixation for the treatment of unstable thoracolumbar fracture with partial or intact neurology. J Orthop Surg Res. 2009;4(1):1-6. https://doi.org/10.1186/1749-799X-4-28 PMid:19635134 PMCid:PMC2724433 